\section{Strategic factors for the sustainability of a health intervention at municipal level of Brazil}

\author{
Fatores estratégicos para a sustentabilidade de \\ uma intervenção na saúde em nível \\ municipal no Brasil
}

\section{Factores estratégicos para la sostenibilidad de una intervención en el ámbito de la salud a nivel municipal en Brasil}

Sydia Rosana de Araujo Oliveira 1 Maria Guadalupe Medina 2 Ana Cláudia Figueiró 3

Louise Potvin 4

doi: 10.1590/0102-311X00063516

\begin{abstract}
The present study aims to describe the evolution of an intervention, using a methodology that adopts the critical event as the unit of analysis, and to identify strategic factors that facilitate the continuation of the interventions. Six critical events were identified: dispute care models for health; area of advice: dispute field; change policy; break of interorganizational relations; lack of physical structure and turnover of staff; difficulty in organizing practices in the work process. these are developed into strategic factors: enabling network of allies; meetings and educational activities/building capacity; benefits perceived by community members; mobilization of key actors; intervention's compatibility with the government's vision; restoration of interrelationship; and stability of the workforce. These strategic factors form a group of interrelated conditions that provide the strengthened linkages between elements in the intervention, supporting the hypothesis that they collaborate for the sustainability of the interventions in health. Tracking down the transformations of an intervention set by the critical events, it was verified that these factors performed a protective role at times of changes in the intervention process.
\end{abstract}

Policy Making; Primary Health Care; Program Evaluation

\author{
Correspondence \\ S. R. A. Oliveira \\ Instituto Gonçalo Muniz, Fundação Oswaldo Cruz. \\ Rua Waldemar Falcão 121, Salvador, BA 40296-710, Brasil. \\ sydiaraujo@gmail.com \\ 1 Instituto Gonçalo Muniz, Fundação Oswaldo Cruz, \\ Salvador, Brasil. \\ 2 Instituto de Saúde Coletiva, Universidade Federal da Bahia, \\ Salvador, Brasil. \\ 3 Escola Nacional de Saúde Pública Sergio Arouca, Fundação \\ Oswaldo Cruz, Rio de Janeiro, Brasil. \\ 4 Université de Montréal, Montréal, Canada.
}




\section{Introduction}

In the literature on the evolution of public and populational health programs, "sustainability" is the term commonly used to designate the continuation of interventions over time 1,2,3. Various expressions have been used to label this phenomenon, and sustainability is the last level of this process that develops in layers 4,5. This procedural connotation of the interventions breaks the model of stages and highlights the dynamic evolution of interventions. The aim of the present study is to describe the evolution of an intervention, and to identify strategic factors that may contribute to the sustainability of public health intervention, from the actors' strategies in critical events.

Explaining the process by which interventions become sustainable has become a growing concern in the field. Some studies have identified factors influencing positively the sustainability of interventions - political support, funding stability, partnerships, organizational capacity, program evaluation, program adaptation, strategic planning, organizational learning, capacity building 5,6,7,8,9,10,11,12,13,14; and negatively - staff turnover, changing medical practice, the low level of initial implementation of the project and lack of training for participants in the intervention 15,16,17. However, few studies have elucidated how these factors interact in this process.

The dynamics of the development of interventions is understood through the concept of critical event 18 . They are relevant units of observation which allow us to place elements in temporal sequence 19 associated with the concept of controversy 20 , capture conditions that destabilize routines and require mediation and actions in order to change or reinforce the trajectory of an intervention. Critical events are those which generate consequences and lead to the reconfiguration of the intervention 21 . The meaning of critical events may vary according to different perspectives of those involved in the development of the intervention.

We hypothesized that, in the destabilizing process associated with controversies, critical events that lead to the restabilization of the program are pervaded by "strategies" deployed by actors, just as controversies are expressions of destabilizing factors. These strategic factors enable a reconfiguration of the intervention and mark the continuation of the program. Strategic factors move interventions forward.

The present study aims to describe the evolution of an intervention, using a methodology that adopts the critical event as the unit of analysis, and to identify strategic factors that facilitate the continuation of the interventions. The data concerns a research and intervention project on primary care in the Northeast region of Brazil that forms one of the three studied sites of a research project that examines processes and tools related to intersectoral management, research and training practices and how they support the sustainability of innovative interventions of health promotion 22 .

\section{Methods}

The present study focuses on an initiative of the Brazilian Federal Government, adopted in 1994 as national policy, which aimed to reorganize the Brazilian healthcare system, by providing universal, all-round, effective health care. The Family Health Program (FHP) is based on primary health care, within the context of families and communities. Multidisciplinary teams implemented the program. In recent decades, it has become the largest primary health care program in the world, being responsible for attending, in 2015, to more than 120 million individuals, covering the entire Brazilian national territory, with a little more than 39,000 family health units (FHU).

This national intervention was introduced in Camaçari, a municipality in the state of Bahia, in 1998. The implementation occurred in a privileged context, in a space of articulated recognition of common interests between individuals (managers, health professionals and community leaders). Even understanding that this intervention suffers influences from both national and state levels, this dynamics of negotiations, mediations and controversies at local level turned the FHP into a unique experience.

As a way of understanding the evolution of the intervention, it was decided to draw up a genealogy of the intervention, which allows tracing the negotiations between the actors and their interests. The genealogy of the intervention reveals through events the interests and transformations that criti- 
cally guide the development of the program 23 . Critical events are understood to mark and generate changes in health interventions, allowing their solidity or dissent. Such events are associated with controversies, obstacles or conflicts that oblige the network of actors to renegotiate distinct interests.

These events that enable us to explicitly outline the transformations that have occurred in a health intervention can be captured using an analytical tool - the Critical Event Card (CEC), which was modeled on the Actor-Network Theory (ANT) 21. According to the ANT, elements and dynamics exist within a socio-technical network that defines the system in action, making it possible to follow its evolutions and structures 20 . The ANT provided the conceptual tools that were used to create the genealogy of the intervention, which is graphically represented as a timeline.

The genealogy of the intervention was initially drawn up on the basis of technical documents of the Municipal Secretariat of Health of Camaçari, produced between 1997 and 2011. Events that were associated with either the consolidation of the intervention or with significant changes within the interventions were organized in the form of a timeline.

The timeline was presented during an interview with key players, identified in four project preparation workshops with representatives of the three components of the overall project - research, teaching, and intersectoral coordination -, key agents were chosen according to their degree of involvement in the intervention and their connection to one of three components. Besides the initial timeline, a semi-structured script guided the interviews, aiming to gather detailed information on the events previously identified and find out about other events that may have been missed through the examination of documents.

All the interviews were recorded and literally transcribed in Portuguese, totaling 18 hours and 23 minutes of interviews. The redefinition of the critical event was subsidized by the consecutive reading of transcribed interviews, which were subjected to various forms of marking, seeking to identify meaning units, confirmation of the categories, and consequently the very critical events. Then, by rereading passages from the interviews, the events were confirmed or excluded from the timeline.

The critical events were described using an analytical tool, the CEC (Table 1), that was based on the ANT and has the following descriptors: (a) actants involved in the event; (b) the interactions between actants; (c) the mediations performed; (d) the actions that took place; (e) the inscriptions produced; and (f) the consequences for the intervention's orientation 21. Critical events were considered by the authors as those which were clearly described by key players and whose consequences, in terms of changes in the activities were clearly defined.

Analyzing the consequences of the critical events and the restabilization process that occurred with the intervention, it was identified that in each critical event there was a set of factors that were central in the consolidation of the intervention, which defined its reconfiguration. Those factors were called strategic factors, and allowed the continuity of the FHP in the studied period.

In the process of analyzing the data, the critical events were not distributed under the three components previously defined - research, teaching, and intersectoral coordination. It was noted that there was an approximation of the critical events as for intersectoral coordination, demonstrating that there is more controversy to such component than the orders. As a result, the three components were used for the description of the research results.

Finally, the key players validated the critical events on three occasions, using an adapted version of the consensus conference technique 24 with a view to reaching, through a plurality of views and not just the observation of the researcher, a rational consensus on the part of all those participating in the research.

In conducting this study, all the ethical recommendations complied with and the research was approved by the Ethics Research Committee - Brazil. The interviews were applied after a Term of Free Informed Consent had been signed and the anonymity and confidentiality of the information relating to each individual were ensured. 


\section{Table 1}

The critical event card.

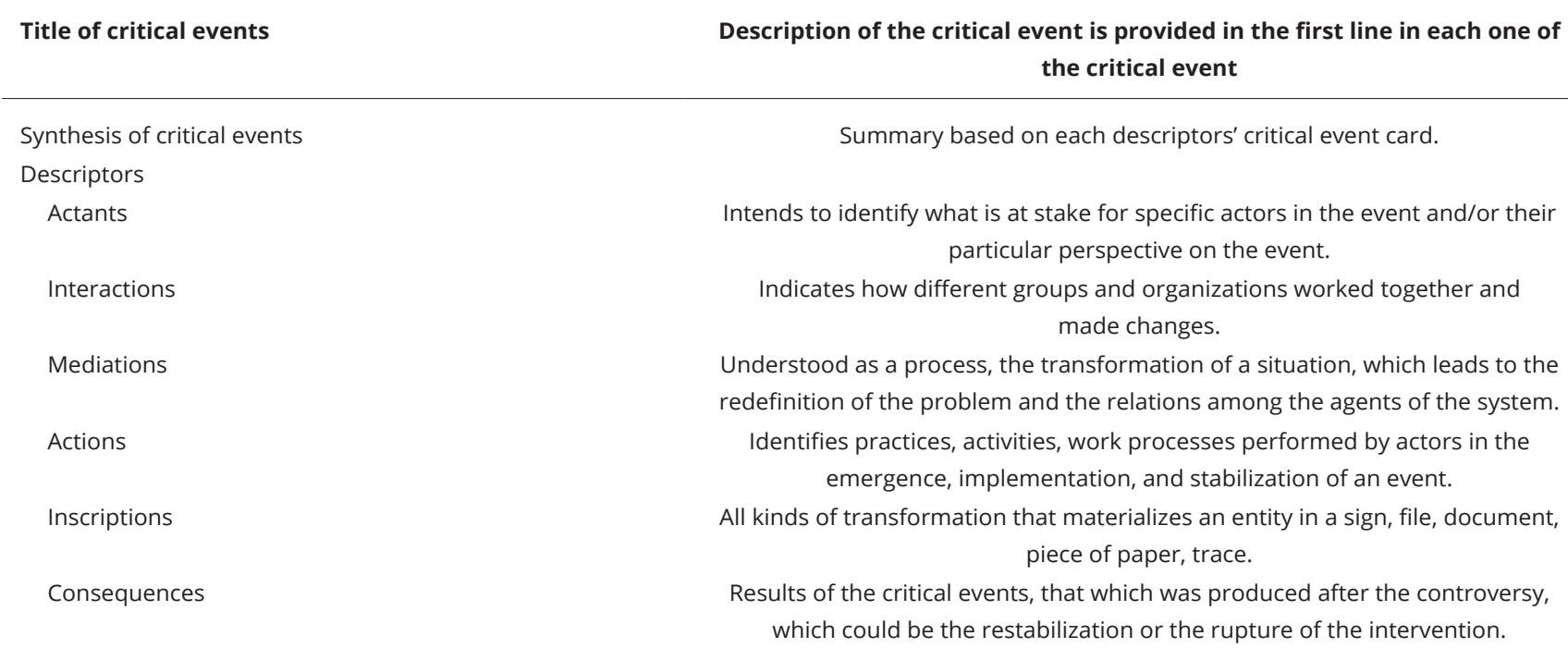

\section{Results}

To present the program as it evolved during the time period being analyzed (1998-2010) (Figure 1). After data analysis, six critical events were identified: dispute care models for health; area of advice: dispute field; change policy; break of interorganizational relations; lack of physical structure and turnover of staff; difficulty in organizing practices in the work process.

The six critical events identified comprise major controversies that took place during the life of the intervention; however there was a set of interrelated conditions, the strategic factors, which allowed the reconfiguration of the intervention and provided the conditions for its sustainability, which are highlighted in the description of critical events. They were: enabling network of allies; meetings and educational activities/building capacity; benefits perceived by community members; mobilization of key actors; intervention's compatibility with the government's vision; restoration of interrelationship; and stability of the workforce.

Detailed description of critical events of the reconstruction of the Camaçari FHP intervention and its strategic factors.

\section{Critical event 1: dispute care models for health}

In 1998, the Camaçari FHP was implemented in a process, which entailed changes in the organization of existing services, specifically the replacement of medical experts, who worked in traditional units, by general practitioners, and replacement attention to spontaneous demand, by a process of the form of organization work involved in organized service offering. The competition of these two distinct approaches for the delivery of health services organization was a controversial point requiring negotiation between the actors involved, in particular, health professionals and local management - intervention of supporters -, and local leaders and other representatives of the population - FHP opponents. To overcome this confrontation, there was the activation of the network of allies who had experience in the initiative and were committed to the success of the intervention, and used, as a strategy to support the intervention, educational meetings and activities in the community to explain the way of organizing. This initiative intervention favored the perception of benefits by community members and accession to the FHP. 


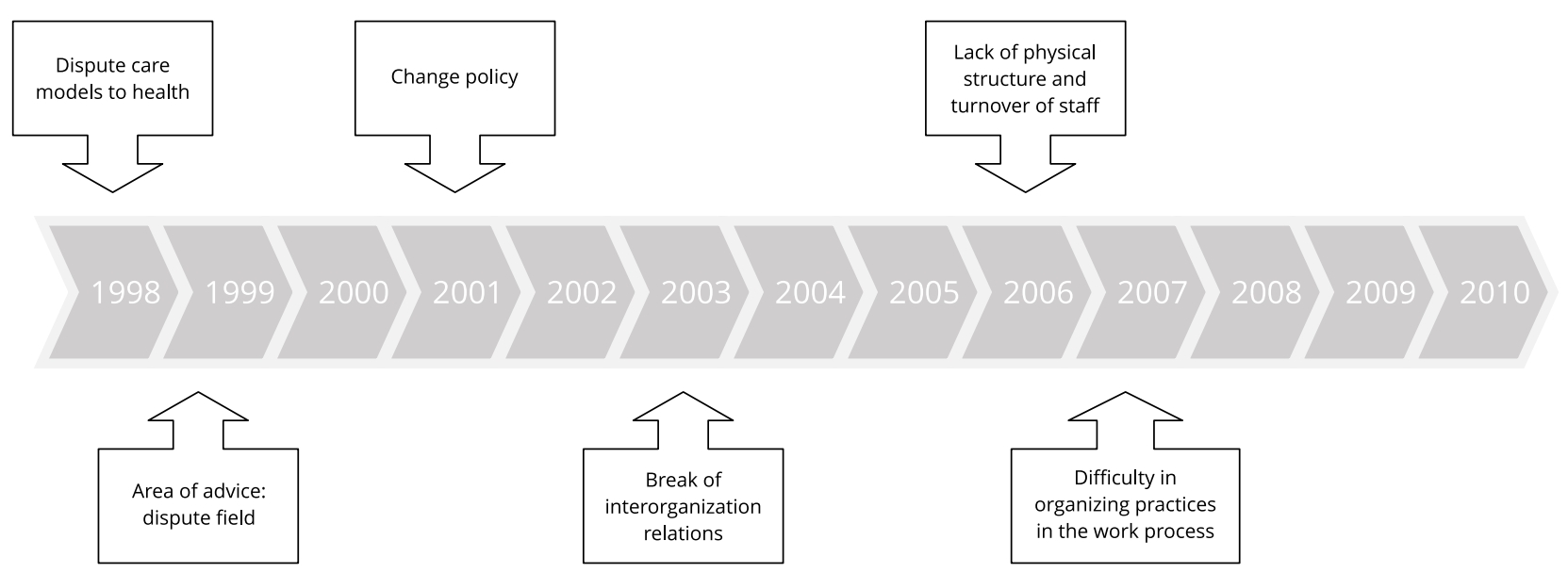

\section{Critical event 2: area of advice: dispute field}

The Local Health Councils, instances of participation and social control, were deployed in tandem with the expansion of the FHPs. However, the increasing involvement of the representatives of the Local Health Councils with supporters and political interests, subordinating the interests of the population on health issues, fostered a community of disbelief in the activities of the FHP, and consequently, the cancellation of some councils and/or operation discontinuity of others. This process of rupture was only reversed in the following years, with the approach of the 4th Municipal Health Conference, with the mobilization of key actors in the reconfiguration supporting community participation. It is observed thus a growing process of popular participation and reorganization of collegiate opportunities for citizen participation.

\section{Critical event 3: change policy}

The decision of the municipal government to take the FHP, a priority government project, has enabled its rapid expansion, with 21 FHU in 2001. However, the output of the Local Health Manager in 2001, and other political changes in the city resulted in disorganization of primary care, and, consequently, disruption in the organization and performance of the FHP. This situation was reversed in November 2005, with the arrival of a new Local Health Manager, which defines as a government project the restructuring and reorganization of the FHP. Thus, the intervention's compatibility with the government's vision allowed the reconfiguration of the intervention.

\section{Critical event 4: break of interorganizational relations}

After the implementation of the first FHU in the capacity building perspective, the Local Health Manager invites the Social Medicine Residency of the Federal University of Bahia to establish in the city its training and research field. However, the lack of structure of primary care services and the breakdown in the organization of the work processes that were observed in the years subsequent to the exit of the Local Health Manager result in the interruption of the cooperation between academy and municipality in 2003. With the change of municipal management in 2006, there is the mobiliza- 
tion of key actors, among them the municipal health management professionals, who had ties with the Residency in Family Health, thus allowing the restoration of interrelationship with the University, having become the FHP of the municipality once again a training course and Research in Social Medicine Residency. This process of partnership with research and teaching institution is extended to other universities in the region.

\section{Critical event 5: lack of physical structure and turnover of staff}

The FHP deployment decision in the municipality was guided by strategies that effectively facilitated intervention. It points to the availability of physical infrastructure and logistics and the careful choice of professionals who composed the FHP, however without conducting the public tender. The disorganization of the FHP, arising out of the local health manager, triggered the dissatisfaction of professionals who began to question the plurality of labor relations. In 2006, the definition of the FHP as a priority project of the government allowed the physical restructuring of existing units and the construction of new units for those with no possibility of restructuring. The compatibility of the intervention with the government's vision unleashed the building of human resources policy, and consequently, conducted public tender for professionals in the FHU. However, the effectiveness of the new gazetted happens abruptly with the output of all professional contractors, at once, bringing temporary instability for the intervention. The restoration of professionals in the intervention was effective in getting along slowly. It is understood that the stability of the workforce will enable the continuity of the intervention.

\section{Critical event 6: difficulty in organizing practices in the work process}

In 2006, with the prioritization of the FHP by the Health Manager, we could observe an interest related to the organization of practices of the teams' work process, especially territorialization, articulation of basic health units as nuclei of reference for the FHU, and definition of institutional supporters in the monitoring and supervision of the intervention. These bold proposals were discussed with the population through the public participation in forums, being well received by the community. With the political change between late 2006 and mid-2007, we can see refusal from the coordinators in supporting innovative practices proposals. The organization of the practices in the FHP suffers from this process, with the need to reconfigure the relationships and initiatives. This destabilization process begins to be modified with the mobilization of actors in the network, which defined new approaches to the reorganization of practices, by building capacity and enhancement of lifelong learning practices. FHP's professionals and local managers began to interact in order to support and collectively build the intervention by developing practical exchange of knowledge, allowing activation of the network of allies, which enhanced the intervention.

\section{Discussion}

This study aimed to identify strategic factors that contributed to the sustainability of the FHP of Camaçari. We found that the seven strategic factors form a group of interrelated conditions that provide the strengthened linkages between elements in the intervention, supporting the hypothesis that they collaborated for the sustainability of the interventions in health.

It is understood that the critical events set the dynamics of the program, but the strategic factors determine program trajectory. These strategic factors are seen as situations in which actors build and deploy strategies that may stabilize the interventions and give them solidity.

Whereas the controversies express different points of view and diverging interests of the actors 18 , the strategic factors strengthen the intervention. An intervention may collapse at the time of mobilization, but the presence of strategic factors contributes to its continuation. Such protective conditions of interventions serve as supporting pillars. At the same time that the intervention is destabilized, there is a mechanism in place that strengthens it and does not let it collapse. 
Enabling network of allies enhances the fit between the intervention and the local context, with consequent adaptation in the evolution of the problems that may interfere with the sustainability ${ }^{6,12}$. Actors, which can be individuals, key members of the community, and organizations, should approach the intervention in order to create networks and carry out an "effective cooperation", strengthening program goals and promoting coordinated efforts 4,5,8,9.

Observing the findings regarding the meetings and educational activities/building capacity, it is noted that these maximize the sharing of information among the actors 25,26 , besides awakening a multiplier role in those involved. This guarantees the expansion of the scope of this educative process of support to the intervention 19,27.

Benefits Perceived by community members/or users has been shown to be important for sustainability by other studies $6,16,28$. It is understood that this factor would result from the influence of capacity building that would allow the assimilation of benefits by team members or the community. It is observed in this study that this factor was a result of a joint process of meetings and educational activities of the professionals involved in the intervention.

The presence of a mediator/key actor is essential to create a supportive environment and facilitate innovative and sustainable practices $3,5,26,29,30,31,32$. The intervention may be stabilized by the positive influence of some key members, establishing links between the individuals, who in turn start to advocate in favor of the intervention ${ }^{9}$. The research points to the need to develop mechanisms that can guarantee the renovation of champions in the ambit of interventions ${ }^{33}$. This enables the growth of the Social-Technical Network and the search for new allies to guarantee the solidity of the intervention 34 .

The literature on sustainability points out that infrastructure and stability of the work force are decisive factors of sustainability 10,26. It also recognizes the existence of a relationship between the degree of institutionalization of a program and its compatibility with the government's vision 2,9,13,35. In this study, the intervention was strengthened by its definition as a municipal government project, supported by the population and local managers.

It can be affirmed that interrelationship between the FHP and other institutions was recognized as essential, especially regarding the sustainability of the intervention $1,7,11,16,25,36$. It was noted that the development of alliances with other sectors guaranteed the construction of an intersectoral space for collaboration. These interorganizational relationships enable, at timely moments, the activation of the networks. As a result, exchange of innovations between groups can take place, constantly renovating the program 9,37 .

In order to systematize the information presented, a summary table was constituted with potential contributors of strategic factors for the sustainability of interventions (Table 2).

\section{Conclusion}

The strategic factors presented in this study coincide a great deal with those found in the literature on sustainability. However, the perspective used to understand these factors as strategies adopted by the actors to restabilize the intervention points to a differentiated rationale. It is believed that these strategic factors link a critical event to the next, interacting and forming a protective network that allows the progress of interventions. Without the strategic factors, the restabilization of the intervention may still happen, however not necessarily for the continuation of the program. The presence of a strategic factor compensates for other weaknesses that might appear to create a rupture of the intervention. It serves, therefore, as a protective factor to ensure continuation.

This work has revealed that interventions can be more durable, due to the presence of strategic factors. Tracking down the transformations of an intervention set by the critical events, it was verified that these factors performed a protective role at times of changes in the intervention process. It was observed that the changes in the interventions are successive, and that, as such, new strategic factors will appear. This allows the adaptation of the interventions in case of de-stabilization processes that may arise. It is worth highlighting the importance of new research that can corroborate the strategic factors presented in this study, or even identify other possible strategic factors for the sustainability of interventions in health. 


\section{Table 2}

Summary table with potential contributives of strategic factors for the sustainability of interventions.

\section{Critical event}

Main controversies

- Changes in the organization of existing services;

- Substitution of medical experts.

2. Area of advice: dispute field.

3. Change of policy.

4. Break of interorganizational relations.

5. Lack of physical structure and turnover of staff.

6. Difficulty in organizing practices in the work process.
- Political-partisan interest from councilors, subordinating the interests of the population.

- Exit of the local health manager;

- Disruption in the organization and performance of the Family Health Program;

- Interruption of the cooperation between academy and municipality.

- Dissatisfaction of health professionals;

- Lack of structure of primary care services.

- Lack of support for carrying out new practices;

- Disruption of work processes.
Potential contributives of strategic factors

for sustainability

"Effective cooperation" (strengthening the objectives of the intervention, promoting coordinated efforts);

Adaptation (enhances the fit between the intervention and the local context);

Multiplier effect (maximization of information shared among the agents);

Training allows the assimilation of the benefits by staff or community members.

Key members advocate in favor of intervention;

Search for new allies.

Adherence to formal structures;

Integration with the organization mission.

Alliances with other sectors guaranteed an intersectoral space for collaboration;

Establishment of connection among individuals.

Staff involvement in decision making and negotiations concerning the intervention;

Stability of the workforce.

Trained subjects (train community members form a constituency in support of the intervention);

Strategic partnerships allow exchange of innovations;

Guarantee in the renewal of champions within the scope of interventions. 


\section{Contributors}

S. R. A. Oliveira contributed in the drafting the work, revising it critically for important intellectual content. M. G. Medina and A. C. Figueiró made substantial contributions to the conception, design of the work, collection, analysis and interpretation of data for the work. L. Potvin contributed in the revision and final approval of the version to be published.

\section{Acknowledgments}

To the Municipal Secretariat of Health of Camaçari and all engaged in the Stratégies d'Institutionnalisation des Interventions Innovantes en Matière d'Équité en Santé au Brésil: un Projet Pilote.

\section{References}

1. Alexander JA, Weiner BJ, Metzger ME, Shortell SM, Bazzoli GJ, Hasnain-Wynia R, et al. Sustainability of collaborative capacity in community health partnerships. Med Care Res Rev 2003; 60:130-60.

2. Bopp M, Saunders RP, Lattimore D. The tugof-war: fidelity versus adaptation throughout the health promotion program life cycle. J Prim Prev 2013; 34:193-207.

3. Mancini JA, Marek L. Sustaining communitybased programs for families: conceptualization and measurement. Fam Relat 2004; 53:339-47.

4. Pluye P, Potvin L, Denis J-L. Making public health programs last: conceptualizing sustainability. Eval Program Plann 2004; 27:121-33.
5. Shediac-Rizkallah MC, Bone LR. Planning for the sustainability of community-based health programs: conceptual frameworks and future directions for research, practice and policy. Health Educ Res 1998; 13:87-108.

6. Chambers DA, Glasgow RE, Stange KC. The dynamic sustainability framework: addressing the paradox of sustainment amid ongoing change. Implement Sci 2013; 8:117.

7. Schell SF, Luke D, Schooley MW, Elliott MB, Herbers SH, Mueller NB, et al. Public health program capacity for sustainability: a new framework. Implement Sci 2013; 8:15. 
8. Scheirer MA. Linking sustainability research to intervention types. Am J Public Health 2013; 103:e73-80.

9. Steckler A, Goodman RM. How to Institutionalize health promotion programs. Am J Health Promot 1989; 3:34-43.

10. Wiltsey Stirman S, Kimberly J, Cook N, Calloway A, Castro F, Charns M. The sustainability of new programs and innovations: a review of the empirical literature and recommendations for future research. Implement Sci 2012; 7:17.

11. Savaya R, Spiro SE. Predictors of sustainability of social programs. Am J Eval 2012; 33:26-43.

12. Hanson HM, Salmoni AW, Volpe R. Defining program sustainability: differing views of stakeholders. Can J Public Health 2009; 100:304-9.

13. Friend S, Flattum CF, Simpson D, Nederhoff DM, Neumark-Sztainer D. The researchers have left the building: what contributes to sustaining school-based interventions following the conclusion of formal research support? J Sch Health 2014; 84:326-33.

14. Oliveira SRA, Potvin L, Medina MG. Sustentabilidade de intervenções em promoção da saúde: uma sistematização do conhecimento produzido. Saúde Debate 2015; 39:1149-61.

15. Goodson P, Murphy Smith M, Evans A, Meyer B, Gottlieb NH. Maintaining prevention in practice. Am J Prev Med 2001; 20:184-9.

16. Scheirer MA. Is sustainability possible? A review and commentary on empirical studies of program sustainability. Am J Eval 2005; 26:320-47.

17. Koskan A, Friedman DB, Messias DK, Brandt HM, Walsemann K. Sustainability of promotora initiatives: program planners' perspectives. J Public Health Manag Pract 2013; 19:E1-9.

18. Oliveira SRA. Sustentabilidade da Estratégia Saúde da Família: o caso de um município baiano. Salvador: Universidade Federal da Bahia; 2014.

19. Pluye P, Potvin L, Denis J-L, Pelletier J, Mannoni C. Program sustainability begins with the first events. Eval Program Plann 2005; 28:123-37.

20. Latour B, Woolgar S. Vida de laborátorio: a produção dos fatos científicos. Rio de Janeiro: Editora Relumé Dumara; 1997.

21. Figueiro AC, Oliveira SRA, Hartz Z, Couturier Y, Bernier J, Freire MSM, et al. A tool for exploring the dynamics of innovative interventions for public health: the critical event card. Int J Public Health 2017; 62:177-86.

22. Potvin L, Hartz ZMA, Aquino R, Clavier C, Couturier Y. Stratégies d'institutionnalisation des interventions innovantes en matière d'équité en santé au Brésil: un projet pilote. Montréal: Université de Montréal; 2010.

23. Bisset S, Potvin L. Expanding our conceptualization of program implementation: lessons from the genealogy of a school-based nutrition program. Health Educ Res 2006; 22:737-46.
24. Souza LEPF, Vieira-da-Silva LM, Hartz ZMA. Conferência de consenso sobre a imagem-objetivo da descentralização da atenção à saúde no Brasil. In: Hartz ZMA, Vieira-da-Silva LM, organizadores. Avaliação em saúde: dos modelos teóricos à prática na avaliação de programas e sistemas de saúde. Salvador: EDUFBA/Rio de Janeiro: Editora Fiocruz; 2005. p. 41-74.

25. Hanson HM, Salmoni AW. Stakeholders' perceptions of programme sustainability: findings from a community-based fall prevention programme. Public Health 2011; 125:525-32.

26. Johnson K, Hays C, Center H, Daley C. Building capacity and sustainable prevention innovations: a sustainability planning model. Eval Program Plann 2004; 27:135-49.

27. Bossert TJ. Can they get along without us? Sustainability of donor-supported health projects in Central America and Africa. Soc Sci Med 1990; 30:1015-23.

28. Huijg JM, Crone MR, Verheijden MW, van der Zouwe N, Middelkoop BJC, Gebhardt W. Factors influencing the adoption, implementation, and continuation of physical activity interventions in primary health care: a Delphi study. BMC Fam Pract 2013; 14:142.

29. Scheirer MA. The life cycle of an innovation: adoption versus discontinuation of the fluoride mouth rinse program in schools. J Health Soc Behav 1990; 31:203-15.

30. Rogers EM. Diffusion of preventive innovations. Addict Behav 2002; 27:989-93.

31. Van Acker R, De Bourdeaudhuij I, De Cocker K, Klesges LM, Willem A, Cardon G. Sustainability of the whole-community project '10,000 Steps': a longitudinal study. BMC Public Health 2012; 12:155.

32. Savaya R, Spiro S, Elran-Barak R. Sustainability of social programs: a comparative case study analysis. Am J Eval 2008; 29:478-93.

33. Neville D, Potvin L, MacDonald L, Williams W, Pluye P, Blaire L, et al. What are the key factors and processes associated with sustained environmental change supportive of health promotion? Montréal: Institut de Recherche en Santé Publique, Université de Montréal; 2000.

34. Latour B. A esperança de pandora. Bauru: EDUSC; 2001.

35. Whelan J, Love P, Pettman T, Doyle J, Booth $\mathrm{S}$, Smith E, et al. Cochrane update: predicting sustainability of intervention effects in public health evidence: identifying key elements to provide guidance. J Public Health (Oxf) 2014; 36:347-51.

36. Swerissen H, Crisp BR. The sustainability of health promotion interventions for different levels of social organization. Health Promot Int 2004; 19:123-30.

37. Paine-Andrews A, Fisher JL, Campuzano MK, Fawcett SB, Berkley-Patton J. Promoting sustainability of community health initiatives: an empirical case study. Health Promot Pract 2000; $1: 248-58$. 


\section{Resumo}

O estudo busca descrever a evolução de uma intervenção, utilizando uma metodologia que adota o evento crítico como unidade de análise, além de identificar fatores estratégicos que facilitam a continuação das intervenções. Foram identificados seis eventos críticos: modelos em disputa na assistência à saúde; área de conselhos: campo de disputa; mudanças de politicas; quebra de relações entre organizações; falta de infraestrutura física e rotatividade de equipes e dificuldade na organização das práticas no processo de trabalho. Os eventos foram desdobrados em fatores estratégicos: potencialização de uma rede de aliados; reuniões e atividades educacionais ou de capacitação; benefícios percebidos pelos membros da comunidade; mobilização de atores-chave; compatibilidade da intervenção com a visão do governo; restauração do inter-relacionamento e estabilidade da força de trabalho. Esses fatores estratégicos formam um grupo de condições inter-relacionadas que fortalecem a articulação entre os elementos da intervenção, sustentando a hipótese de que colaboram com a sustentabilidade das intervenções na saúde. Ao identificar as transformações de uma intervenção relacionadas aos eventos críticos, verificou-se que esses fatores desempenharam papel protetor em momentos de mudanças no processo da intervenção.

Formulações de Políticas; Atenção Primária à Saúde; Avaliação de Programas e

Projetos de Saúde

\section{Resumen}

El estudio busca describir la evolución de una intervención, utilizando una metodología que adopta el evento crítico como unidad de análisis, además de identificar factores estratégicos que facilitan la continuación de las intervenciones. Se identificaron seis eventos críticos: modelos en disputa en la asistencia a la salud; área de consejos: campo de disputa; cambios de politicas; ruptura de relaciones entre organizaciones; falta de infraestructura física y rotatividad de equipos y dificultad en la organización de las prácticas en el proceso de trabajo. Los eventos fueron desdoblados en factores estratégicos: potencialización de una red de aliados; reuniones y actividades educacionales o de capacitación; beneficios percibidos por los miembros de la comunidad; movilización de actores-clave; compatibilidad de la intervención con la visión del gobierno; restauración de la interrelación y estabilidad de la fuerza de trabajo. Estos factores estratégicos forman un grupo de condiciones interrelacionadas que fortalecen la articulación entre los elementos de la intervención, manteniendo la hipótesis de que colaboran con la sostenibilidad de las intervenciones en la salud. Al identificar las transformaciones de una intervención relacionadas con los eventos críticos, se verificó que esos factores desempeñaron un papel protector en momentos de cambios en el proceso de la intervención.

Formulación de Politicas; Atención Primária de Salud; Evaluación de Programas y

Proyectos de Salud
Submitted on 13/Apr/2016

Final version resubmitted on $03 / \mathrm{Aug} / 2016$

Approved on 08/Sep/2016 